\title{
Екстракорпоральна ударно-хвильова терапія як метод неінвазивного лікування ентезопатій
}

\author{
'В. М. Чорний, ${ }^{1}$ М. Л. Головаха, ${ }^{2}$ В. Ю. Юрків, \\ ${ }^{3}$ В. Г. Маріхін \\ 1Запорізький державний медичний університет, \\ ${ }^{2}$ Клініка «Мотор Січ», \\ ${ }^{3}$ Міська клінічна лікарня, Запоріжжя, Україна
}

Резюме. Рассмотрены влияние экстракорпоральной ударно-волновой терапии на лечение энтезопатий, а также типы приборов, используемых во время проведения лечебных процедур. Дан анализ результатов проведенного лечения.

Ключевые слова: экстракорпоральная ударно-волновая терапия, энтезопатии.

Summary. Effects of extracorporeal shock wave therapy in the treatment of enthesopathy, and the types of medical equipment used for intervention are outlined. The results of the treatment are analyzed.

Keywords: extracorporeal shock wave therapy, enthesopathy.

Захворювання, пов'язані з перенапруженням опорно-рухового апарату, $\epsilon$ однією $з$ найгостріших проблем сучасної травматології та ортопедії [4]. Різні стереотипні або періодичні навантаження, що повторюються, здатні викликати хворобливі стани у людей, професійно пов'язаних із такими навантаженнями, й у малотренованих та людей похилого віку, які становлять більшість міського населення.

У медичній літературі існує термін «ентезопатії», що позначає дегенеративно-дистрофрічні процеси у місцях прикріплення зв'язок, сухожиль, капсул суглобів до кісток внаслідок перевантаження. За даними досліджень, процес починається в місцях переходу сухожилля, зв'язки або капсули у кістку на рівні хрящової зони і не завжди зачіпає сухожилля або зв'язку [1-3].

При перевантаженні в пластинці волокнистого хряща починають формуватися ділянки, де проходить дегенеративно-дистрофічний процес, що характеризується деформацією поздовжньо спрямованих сухожилкових волокон та хаотичним розташуванням фріброцитів [8].

Деякі дослідники [10] відмічають втрату блиску сухожилкової або зв'язкової тканини, набряк крихкої сполучної тканини, проліфрерацію фрібробластів і виділення фрібрину. Н. Дебруннер (1947) спостерігав мікротріщини, часткові розриви під час перевантаження. Автор висловив думку, що ці зміни слід розглядати як ентезопатію - хронічне дегенеративне захворювання місця переходу сухожилля або сполучно-суглобової структури в кістку.
Відомо багато видів ентезопатій:

- ARS-синдром (10,5\%);

- PSOAS-сидром (9,0\%);

- ентезопатія великого вертлюга; ції;

- ентезопатія м'яза-натягувача широкої фрас-

- ентезопатія чотириголового м'яза стегна;

- ентезопатія півперетинчастого м'яза;

- арех-синдром $(32,8 \%)$;

- синдром великої «гусячої лапки»;

- ентезопатія пероніального м'яза (10,0%);

- плантарний фрасцит (14,2 \%);

- ентезопатія обертальної манжети плеча $(10,5 \%)$;

- ентезопатія довгої головки біцепса;

- латеральна ентезопатія ліктя (7,1 \%);

- медіальна ентезопатія ліктя;

- ентезопатія трапецієподібного м'яза;

- ентезопатія прямих м'язів спини.

Нові можливості у лікуванні ентезопатій пов'язані із впровадженням в ортопедо-травматологічну практику екстракорпоральної ударно-хвильової терапії (ЕУХТ). Вперше цей метод застосовано на початку $1980-x$ років, коли було створено літотриптер для дроблення конкрементів при сечокам'яній і жовчокам'яній хворобах, завдяки чому вдалося значно скоротити кількість пацієнтів, які мають потребу в оперативному лікуванні.

Акустична хвиля через фріксування і нелінійні притлумлюючі дії рідкого середовища передачі (вода, тканина) отримує сигнал про різкий підйом імпульсного фронту, що спричиняє тиск, 
ТАБЛИЦЯ 1. Типи приладів для ударно-хвильової терапії

\begin{tabular}{|c|c|c|c|}
\hline $\begin{array}{l}\text { № } \\
3 / \pi\end{array}$ & $\begin{array}{c}\text { Рік } \\
\text { застосування }\end{array}$ & Тип приладу & Принцип дії \\
\hline 1 & 1980 & $\begin{array}{l}\text { Електрогідравлічний генератор з } \\
\text { еліпсоїдним поширенням хвилі }\end{array}$ & $\begin{array}{l}\text { Акустична хвиля створюється у рідкому середовищі за допомогою елек- } \\
\text { тричного розряду (принцип свічки запалювання) }\end{array}$ \\
\hline 2 & 1985 & $\begin{array}{l}\text { П'єзоелектричний генератор з по- } \\
\text { ширенням хвилі у вигляді сфери }\end{array}$ & $\begin{array}{l}\text { Високовольтний імпульс викликає розширення п'єзокристалів, розташо- } \\
\text { ваних на параболічній поверхні }\end{array}$ \\
\hline 3 & 1986 & $\begin{array}{l}\text { Електромагнітний генератор } 3 \\
\text { акустичною лінзою }\end{array}$ & $\begin{array}{l}\text { Високовольтний розряд через котушку (циліндричну або пласку) викли- } \\
\text { кає вихровий струм у розташованій поруч мембрані і відхиляє ї̈̈ відповід- } \\
\text { но до електромагнітного принципу }\end{array}$ \\
\hline 4 & 1989 & $\begin{array}{l}\text { Електромагнітне циліндричне } \\
\text { джерело хвиль }\end{array}$ & Параболоїдне поширення ударних хвиль \\
\hline 5 & 2001 & Пневматичний генератор & $\begin{array}{l}\text { Ударні хвилі генеруються поза тілом пневматичним джерелом, потім } \\
\text { перетворюються і фокусуються в маніпуляторі у звукові хвилі }\end{array}$ \\
\hline
\end{tabular}

внаслідок чого у фокусі виникає ударна хвиля. 3 розвитком методики вдосконалювались генератори ударно-хвильових імпульсів, можливості створення і фрокусування хвиль.

Існують кілька типів приладів для ударно-хвильової терапії, що відрізняються механізмом генерації хвиль: електрогідравлічні, п'єзоелектричні, електромагнітні і пневматичні, котрі вважаються найбільш економічними і безпечними (табл. 1).

На початку 1990-х років метод ЕУХТ почали застосовувати при лікуванні несправжніх суглобів і сповільнено консолідуючих переломів для індукції кісткової мозолі. Наявність надкісткових та інтрамедулярних фріксаторів не $€$ протипоказанням для проведення ЕУХТ, що підтверджується результатами експериментальних досліджень $[6,9]$. У подальших клінічних дослідженнях німецьких учених [5, 7, 9] було відмічено позитивну роль ударно-хвильової терапії у лікуванні псевдоартрозів. До 1991 р. належать перші повідомлення про позитивний ефект даного методу при лікуванні хронічного осифікуючого тендиніту сухожилля ротаторної манжети, підошвового фасциту, ентезопатії латерального та медіального надвиростків плечової кістки тощо.

Щодо механізму дії ЕУХТ на структури м'яких тканин існує кілька теоретичних концепцій, котрі пояснюють виникнення аналгетичного ефректу після іï проведення. Проходження звукових хвиль призводить до руйнування нервових закінчень, або за надмірного подразнення цих закінчень маємо такий самий ефект: розривається рефлекторна дуга передачі больового імпульсу із патологічної ділянки. Крім того, біологічно активні речовини, що утворюються внаслідок еоректу кавітації у зоні впливу ЕУХT, порушують функцію нервових закінчень та індукують регенеративні процеси. Цьому сприяє і локальна гіпотермія. За наявності осифрікатів і відкладень солей кальцію під дією ударних хвиль відбувається їх дезінтеграція, що полегшує розсмоктування макрофрагами. Експерименти на тваринах свідчать про те, що ЕУХТ може стимулювати маркери, які належать до ангіогенезу, і сприяти неоваскуляризації, що покращить кровопостачання i регенерацію тканин.

Методи та організація дослідження. У клініці «Мотор Січ» ударно-хвильову терапію проводять апаратом MASTERPULS MP 200. У зону лікування подають акустичні ударно-хвильові імпульси (УХІ) з частотою 1-21 Гц. Найбільший терапевтичний ефект від їхньої дії відбувається у щільніших тканинах і на межі розподілу тканин: кістка-сухожилля, м'яз-фрасція. Під впливом ударної хвилі відмічається локальне посиленя кровотоку, зміна проникності кліткових мембран, активізація обміну речовин і відновлення кліткового іонного обміну. Цим забезпечується інтенсивне виведення кінцевих продуктів катаболізму, стимуляція відновлювальних процесів тканин, протизапальний та протинабряковий ефект. Дія УXI на ділянку патологічного вогнища розриває порочне коло больових імпульсів, результатом чого $є$ швидке зниження і купірування больового синдрому. В клініці використовують віброголовку D-actor із радіальним поширенням хвилі (табл. 2).

Було проаналізовано результати лікування 157 пацієнтів за період із серпня 2011 р. по вересень 2012 р., із них чоловіків - 86 (55,9\%), жінок - 71 (44,1 \%). Переважна більшість пацієнтів працездатного віку (74 \%), що свідчить про високу соціальну та економічну актуальність проблеми.

Усіх пацієнтів було розподілено на шість груп (табл. 3).

Режим роботи: частота - 1-16 Гц, тиск 1-4 бар, кількість імпульсів 1000-4000, інтервал 7-10 днів. Сеанс триває 5-10 хв і не потребує знеболювання.

Аналіз результатів ЕУХТ проводили за шкалою ВАШ. Було виявлено, що пацієнти після трьох, 
Спортивна медицина, № 1, 2013

ТАБЛИЦЯ 2 - Характеристика віброголовки D-actor

\begin{tabular}{|c|c|c|c|c|}
\hline Головка & Характеристика & Застосування & $\begin{array}{c}\text { Геометрія хвиль / глибина } \\
\text { проникнення }\end{array}$ & $\begin{array}{l}\text { Щільність енергії при } \\
\text { максимальному тиску }\end{array}$ \\
\hline & $\begin{array}{l}\mathrm{R} 15,15 \text { мм } \\
\text { ЕУХT головка, радіальне поширення }\end{array}$ & $\begin{array}{l}\text { Класична РУХТ, усі види } \\
\text { тендинопатій }\end{array}$ & $0-40$ мм & 0,38 мДж $\cdot$ мм² $^{2}$ \\
\hline & $\begin{array}{l}\text { D20, } 20 \text { мм } \\
\text { D-Actorl, віброхвилі, циліндричне } \\
\text { поширення }\end{array}$ & $\begin{array}{l}\text { Міофасціальна тригерна } \\
\text { терапія, лікування м'язової та } \\
\text { сполучної тканини }\end{array}$ & $0-50 \mathrm{мм}$ & 0,48 мДж · мм² \\
\hline
\end{tabular}

ТАБЛИЦЯ 3 - Результати ударно-хвильової терапії

\begin{tabular}{|c|c|c|c|}
\hline Зона ентезопатії & $\begin{array}{c}\text { Кількість } \\
\text { сеансів }\end{array}$ & $\begin{array}{l}\text { Кількість } \\
\text { пацієнтів }\end{array}$ & $\begin{array}{c}\text { Усього } \\
\text { пацієнтів }\end{array}$ \\
\hline \multirow[t]{3}{*}{ Обертальна манжета плеча } & 3 & 21 & \multirow[t]{3}{*}{32} \\
\hline & 5 & 9 & \\
\hline & 7 & 2 & \\
\hline \multirow[t]{3}{*}{ Епікондиліти } & 3 & 18 & \multirow[t]{3}{*}{31} \\
\hline & 5 & 13 & \\
\hline & 7 & - & \\
\hline \multirow[t]{3}{*}{ Плантарний фасцит } & 3 & 29 & \multirow[t]{3}{*}{55} \\
\hline & 5 & 20 & \\
\hline & 7 & 6 & \\
\hline \multirow{3}{*}{$\begin{array}{l}\text { Арех-синдром і синдром } \\
\text { «гусячої лапки» }\end{array}$} & 3 & 16 & \multirow[t]{3}{*}{23} \\
\hline & 5 & 7 & \\
\hline & 7 & - & \\
\hline \multirow[t]{3}{*}{ Ахіллодинія } & 3 & 5 & \multirow[t]{3}{*}{9} \\
\hline & 5 & 1 & \\
\hline & 7 & 3 & \\
\hline \multirow[t]{3}{*}{ Великий вертлюг } & 3 & 2 & \multirow[t]{3}{*}{7} \\
\hline & 5 & 4 & \\
\hline & 7 & 1 & \\
\hline
\end{tabular}

п'яти і семи курсів відмітили зниження больового синдрому (табл. 4).

Результати дослідження та їх обговорення. Аналіз результатів лікування свідчить, що хронічні дегенеративно-дистрофрічні зміни у місцях кістково-сухожилкових з'єднань - поширена патологія, що зустрічається серед дорослого населення. Серед осіб, які займаються спортом або за своєю діяльністю отримують значні навантаження, такі захворювання зутрічаються набагато частіше. Етіологічні передумови та клінічні прояви значно ускладнюють вибір патогенетично обгрунтованої лікувальної тактики. Використовувані для їх лікування фрізіотерапія,

\section{Література}

1. Каннус П. Состав тела и заболевания, предраспалагающие к возникновению травм / П. Каннус / Спортивная травма. - К.: Олимп. лит., 2002. - С. 141-154.

2. Корж $A$. $A$. Диагностика и консервативное лечение заболеваний и повреждений опорно-двигательной системы / А. А. Корж, В. Н. Коваленко, Н. А. Корж. - Х.: Основа, 1998.
ТАБЛИЦЯ 4 - Аналіз результатів за шкалою ВАШ

\begin{tabular}{|l|c|c|c|c|c|c|c|}
\hline \multirow{2}{*}{\multicolumn{1}{|c|}{ Зона ентезопатії }} & \multicolumn{7}{|c|}{ Бали за шкалою ВАш } \\
\cline { 2 - 8 } & $\mathbf{0 - 1}$ & $\mathbf{2 - 3}$ & $\mathbf{4 - 5}$ & $\mathbf{6 - 7}$ & $\mathbf{8 - 9}$ & $\mathbf{0}$ \\
\cline { 2 - 8 } & \multicolumn{7}{|c|}{ Кількість паціснтів } \\
\hline $\begin{array}{l}\text { Обертальна манжета } \\
\text { плеча }\end{array}$ & 19 & 10 & 3 & 0 & 0 & 0 \\
\hline Епікондиліти & 24 & 5 & 1 & 1 & 0 & 0 \\
\hline Плантарний фасцит & 24 & 26 & 3 & 1 & 1 & 0 \\
\hline $\begin{array}{l}\text { Арех-синдром і синдром } \\
\text { «гусячої лапки» }\end{array}$ & 18 & 3 & 2 & 0 & 0 & 0 \\
\hline Ахіллодинія & 6 & 4 & 2 & 1 & 0 & 0 \\
\hline Великий вертлюг & 2 & 4 & 1 & 0 & 0 & 0 \\
\hline
\end{tabular}

нестероїдні протизапальні препарати, ін'єкції кортикостероїдів, лазеротерапія, голко-, рефлексотерапія, масаж, зазвичай, не забезпечують стійкий позитивний ефект. Такі курси лікування забирають до 1,5-2 міс., потребують повторних візитів до лікувальних закладів, а спеціальні медикаментозні засоби мають високу вартість, у деяких випадках $€$ протипоказання до їх застосування, і можуть викликати негативний вплив на організм. У сукупності це створює реальну соціально-економічну проблему.

\section{Висновки}

1. Після проведеного лікування досягається стійкий позитивний ефрект, причому багато пацієнтів уже після першого сеансу могли повернутися до своєї професійної діяльності.

2. Лікування проводиться амбулаторно.

3. Інтенсивність і тривалість дії вибираються залежно від локалізації та ступеня болю.

4. Метод лікування не має вікових обмежень i не потребує відриву від професійної та спортивної діяльності.

\section{References}

1. Kannus P. Body composition and diseases that predispose to the injury occurrence / P. Kannus // sports injury. - Kyiv: Olympic Literature, 2002. - P. 141-154.

2. Korzh $A$. A. Diagnosis and conservative treatment for diseases and injuries of the musculoskeletal system / A. A. Korzh, V. N. Kovalenko, N. A. Korzh. - Kharkiv: Osnova, 1998. 
3. Левенеи В. Н. Спортивная травматология / В. Н. Левенец, Я. В. Линько. - К., 2008. - С. 42-62, 99-102.

4. ЛеВенець В. М. Экстракорпоральна ударно-хвильова терапія в лікуванні ентензопатій / В.М.Левенець, Д. О. Васильев, М. М. Риган // Актуальні питання сучасної ортопедії та травматології: матеріали Всеукр. наук.-практ. конф. 3 міжнар. участю. - К., 2004. - С. 92-99.

5. Мартин Д. Ф. Повреждения стопы / Д. Ф. Мартин // Спорт. травмы. - К.: Олимп. лит., 2003. - С. $207-$ 216.

6. МироноВ С. П. Применение экстракорпоральной ударно-волновой терапии при лечении хронических дегенеративно-дистрофических заболеваний опорно-двигательной системы / С. П. Миронов, Д. О. Васильев, Г. М. Бурмакова // Ветст. травматологии и ортопедии. - 1999. - №1. C. $26-29$.

7. Ренстрем П. А. Ф. Х. Спортивные травмы / под общ. ред. П. А. Ф. Х. Ренстрема. - К.: Олимп. лит., 2002. - C. $59-66$.

8. Becker W. Die tendopathien G. / W. Becker, H. Krahl.Stuttgurt: Thieme Verlag, 1978. - 107 p.

9. Haupt G. rESWT-Terapie beim Fersensporn (Fascitis plantaris)/ G. Haupt et al. //Extrakorporale Stosswellentherapie; ed. L. Gerdesmeyer. - Norgerstedf: Books on Demand $\mathrm{GmbH}, 2004$. - P. 167-182.

10. Tallon C. Outcome of surgery for chronic Achilles tendopathy. A critical review / C. Tallon et. al. // Am. J. Sports Med. - 2001:29:315-20.
3. Levenets V. N. Sports traumatology: Study guide / V. N. Levenets, Ya. V. Linko. - Kyiv: Olympic literature, 2008. - P. 42-62, 99-102.

4. Levenets V. M. Extracorporeal shock wave therapy for the treatment of enthesopathy / V. M. Levenets, M. M. Regan // Actual problems of modern orthopaedics and traumatology: All-Ukrainian. scientific and practical. conf. with the international participation. - Kyiv, 2004. - P. 92-99.

5. Martin D. F. Injuries of the foot / D. F. Martin / / Sports injury. - Kyiv: Olympic Literature, 2003. - P. 207-216.

6. Mironov S. P. The use of extracorporeal shock wave therapy for treatment of chronic degenerative-dystrophic diseases of musculoskeletal system / S. P. Mironov, D. O. Vasiliev, G. M. Burmakova // Vestnik travmatologii i ortopedii imeni Priorova (Priorov bulletin of traumatology and orthopedics). - 1999. - № 1. - P. 26-29.

7. Renström P. A. F. H. Sports injuries / General edition by P. A. F. H. Renström. - Kyiv: Olympic Literature, 2002. P. $59-66$.

8. Becker W. Die tendopathien G. / W. Becker, H. Krahl. -Stuttgurt: Thieme Verlag, 1978. - $107 \mathrm{p}$.

9. Haupt G. rESWT-Terapie beim Fersensporn (Fascitis plantaris)/ G. Haupt et al. //Extrakorporale Stosswellentherapie; ed. L. Gerdesmeyer. - Norgerstedf: Books on Demand $\mathrm{GmbH}, 2004$. - P. 167-182.

10. Tallon C. Outcome of surgery for chronic Achilles tendopathy. A critical review / C. Tallon et. al. // Am. J. Sports Med. - 2001:29:315-20. 